\title{
PERDAGANGAN BERJANGKA KOMODITI DAN KAJIN HUKUM KONTRAK DERIVATIF FOREX DAN INDEKS SAHAM ASING DALAM INDUSTRI PERDAGANGAN BERJANGKA DI INDONESIA
}

\author{
Allysthia M. Renti D. ${ }^{1}$
}

\begin{abstract}
Indonesia is rich in a variety of commodities, but Indonesia also facing its price risk. The government assessed the opportunities for commodity hedging with futures trading. The Law No.32 Year 1997 regarding Commodity Futures Trading was issued as a legal certainty. As a matter of fact, this industry is not growing as expected. On the contrary, numbers of foreign cross currency (forex) and index derivative contract transaction - which is not associated with hedging its underlying assets, are growing rapidly. The derivative contract, which held in bilateral manner (over the counter) is regulated by Decree of Head of Commodity Futures Trading Regulatory Agency. The problems arise since Law No.32 Year 1997 only put multilateral (on exchange) derivative transaction activities in order. However, this industry needs to evaluate and improve its regulation, in order to achieve market liquidity related to hedging (risk management tools) and to protect the citizen and investor as well.
\end{abstract}

Key words: futures trading, derivative contract, bilateral

\begin{abstract}
Abstrak
Indonesia kaya berbagai komoditas, namun Indonesia juga menghadapi risiko harga. Pemerintah menilai peluang untuk memproteksi nilai komoditi dengan perdagangan berjangka. UU No.32 Tahun 1997 tentang Perdagangan Berjangka Komoditi diterbitkan sebagai kepastian hukum. Sebagai fakta, industri ini tidak berkembang seperti yang diharapkan. Sebaliknya, jumlah pertukaran mata uang asing (valas) dan transaksi kontrak derivatif indeks - yang tidak terkait dengan lindung nilai aset yang mendasarinya, yang berkembang pesat. Kontrak derivatif, yang diselenggarakan secara bilateral (over the counter) diatur dengan Keputusan Kepala Badan Perdagangan Berjangka Komoditi Peraturan. Masalah muncul karena UU No.32 Tahun 1997 hanya dalam rangka menempatkan multilateral (kurs) aktivitas transaksi derivatif. Namun, industri ini perlu mengevaluasi dan memperbaiki peraturan, dalam rangka mencapai likuiditas pasar yang berkaitan dengan perlindungan nilai (alat manajemen risiko) dan untuk melindungi warga negara dan investor.
\end{abstract}

Kata kunci: perdagangan berjangka, kontrak derivatif, bilateral

\footnotetext{
${ }^{1}$ Alamat kontak: allysthia.rentiy@yahoo.com
} 


\section{Pendahuluan}

Perdagangan berjangka memang tidak begitu dikenal dibandingkan dengan perdagangan saham atau pasar modal. Padahal melalui pasar berjangka ini, harga pada pasar fisik komoditi yang beragam, seperti produk pertanian, perkebunan dan pertambangan, dapat dilindung nilainya. Lindung nilai (hedging) dilakukan terhadap risiko yang tidak dapat dikendalikan (unmanageable) yang bersumber dari faktor eksternal. ${ }^{2}$ Salah satunya risiko harga yang disebabkan pergerakan harga barang, nilai tukar, tingkat suku bunga ataupun inflasi. Upaya dalam mengurangi risiko fluktuasi harga dilakukan melalui sarana pengelolaan risiko (risk management tool) yang diperoleh melalui instrumen perdagangan berjangka (futures trading). Mekanisme proteksi terhadap risiko harga dilakukan dengan mengalihkan risiko kepada investor yang mengharapkan keuntungan dari perubahan harga yang terjadi.

Perdagangan berjangka adalah kegiatan bisnis yang kompleks, berisiko tinggi dan melibatkan banyak pihak. Maka itu, dibentuk Undang-Undang Nomor 32 Tahun 1997 tentang Perdagangan Berjangka Komoditi sebagai dasar hukum yang kuat untuk memberi kepastian hukum. Pembentukan undang-undang ini terutama pula ditujukan untuk melindungi para petani serta produsen kecil dalam menghadapi era globalisasi dan perdagangan bebas - selain untuk melindungi masyarakat dari tindakan yang merugikan oleh Commision House. ${ }^{3}$ Mekanisme kegiatan perdagangan berjangka ini adalah dengan melakukan transaksi kontrak berjangka di bursa berjangka ${ }^{4}$ yang dilakukan oleh pialang berjangka (sebagai pelaksana amanat/order nasabah) dan pedagang berjangka. Untuk jaminan dalam transaksi tersebut, pialang berjangka menarik sejumlah dana margin kepada nasabah sebagai dana jaminan penyelesaian transaksi.

Kegiatan perdagangan dengan mekanisme penarikan margin juga dilaksanakan pada transaksi kontrak derivatif antar mata uang asing dan indeks di luar bursa. Perdagangan ini berisiko tinggi, namun bisa mendatangkan return yang juga tinggi, sehingga perdagangan ini bersifat high risk high return. Di dunia, jumlah transaksi foreign exchange (forex) di pasar keuangan (baik multilateral maupun bilateral) sudah jauh melampaui jumlah transaksi di pasar riil (ekspor-impor dan perdagangan domestik). ${ }^{5}$ Ini menunjukkan bahwa banyak

\footnotetext{
${ }^{2}$ Pantas Lumban Batu, "Perdagangan Berjangka (Futures Trading)", (Jakarta: Dian Utama, 2008), hal. 19.

${ }^{3}$ Commission House telah muncul sejak tahun 1970-an dan telah menimbulkan banyak kerugian terhadap nasabah atau investor akibat penipuan. Commission House ini merupakan semacam Pialang sekaligus Bandar yang tidak memiliki izin atau ilegal. Mereka beroperasi hanya berdasarkan SIUP.
}

${ }^{4}$ Pelaksanaan perdagangan adalah secara multilateral, yakni terjadi antara banyak pembeli dan banyak penjual, dilakukan di bursa sebagai unsur penyelenggara yang me-match order jual beli tersebut.

${ }^{5}$ Di pasar asing, peningkatan secara tajam dalam perdagangan berjangka terjadi sekitar tahun 1970-an saat mulai munculnya kontrak berjangka melalui instrumen mata uang yang dimulai 
pihak yang lebih berminat pada pasar tersebut. Pada tahun 2001, total nilai perdagangan forex di bursa utama baru mencapai USD1200 miliar per hari, angka ini melonjak menjadi USD1900 miliar per hari pada tahun 2004. Di OTC, pada tahun 2001 total nilainya baru USD575 miliar per hari, sedangkan pada tahun 2004 sudah mencapai USD1200 miliar per hari. ${ }^{6}$ Fenomena serupa ini juga terjadi di Indonesia, namun ketika itu tidak ada yang mengawasi transaksi ini. Dalam arti, transaksi forex secara ritel $^{7}$ juga demikian indeks bebas diperdagangkan saat itu tanpa didasari suatu peraturan perundang-undangan yang menaunginya.

Bappebti kemudian mengeluarkan SK No.55/Kep/BAPPEBTI//2005 tentang Sistem Perdagangan Alternatif (SPA). ${ }^{8}$ Pembentukan SK ini bertujuan untuk memberikan perlindungan kepada masyarakat dan kepastian hukum kepada para pelaku pasar. Sementara, hingga saat ini masih menjadi polemik apakah pengaturan mengenai transaksi antar mata uang asing dan indeks memang tepat diatur dengan suatu surat keputusan Kepala Bappebti. Oleh karena yang diatur dalam UU No.32/1997 adalah perdagangan berjangka yang dilakukan secara multilateral (di dalam bursa). Untuk itu bagi para professional investor serta masyarakat awam, harus memahami mengenai transaksi ini terutama dari segi pengaturannya..

\section{Perdagangan Berjangka Komoditi}

Perdagangan berjangka komoditi (PBK) adalah segala sesuatu yang berkaitan dengan jual beli komoditi dengan penyerahan kemudian berdasarkan kontrak berjangka dan opsi atas kontrak berjangka (Pasal 1 angka 1 UU No.32/1997). Maka itu, dalam PBK yang ditansaksikan adalah berupa kontrak berjangka. Berdasarkan Pasal 1 angka (4) UU No.32/1997, merupakan suatu bentuk kontrak standar untuk membeli atau menjual Komoditi ${ }^{9}$ dalam jumlah, mutu, jenis, tempat, dan waktu penyerahan di kemudian hari yang telah ditetapkan. Barang (komoditi) yang diperjualbelikan tersebut tidak ditransaksikan di tempat secara fisik, tetapi yang ditransaksikan adalah kontraknya di bursa berdasarkan spesifikasi kontrak. Di dalam spesifikasi kontrak dijelaskan antara lain jumlah, mutu, waktu dan tempat penyerahan, yang belum ditentukan adalah

di Chicago. Mata uang asing seperti Swiss Franc dan Yen Jepang adalah yang pertama kali diperdagangkan. Sekitar tahun 1980-an juga mulai diperdagangkan indeks saham seperti S\&P 500. xxiii.

${ }^{6}$ Sawidji Widoatmodjo, et al., "Forex Online Trading", (Jakarta: Gramedia, 2008), hal.

${ }^{7}$ Transaksi derivatif yang meliputi bank, lembaga keuangan non bank, dan perusahaan diatur oleh Bank Indonesia.

${ }^{8}$ Berdasarkan Pasal 4 ayat (1) UU No.32/1997, Bappebti memiliki fungsi pengaturan, pembinaan dan pengawasan sehari-hari kegiatan perdagangan berjangka berdasarkan undangundang.

${ }^{9}$ Yang ditetapkan oleh keputusan Presiden. 
harga. ${ }^{10}$ Dalam kontrak berjangka tidak selalu dilakukan dengan penyerahan fisik, ${ }^{11}$ karena di bursa yang dilaksanakan adalah paper trading, yakni kontrak berjangka yang diperjualbelikan. Dari transaksi yang dilakukan inilah, apabila pasarnya likuid, maka dapat terjadi referensi harga. Maksudnya ialah pelaku di pasar fisik dapat melihat harga yang terbentuk di bursa sebagai harga acuan dari komoditi yang bersangkutan. Hal ini seperti yang terjadi di New York Mercantile Exchange (NYMEX) di mana harga minyak bumi (crude oil) per barel menjadi acuan harga. Pasar yang likuid disebabkan oleh banyaknya pembeli dan banyaknya penjual yang bertransaksi kontrak berjangka terkait.

Sejauh ini, komoditi yang dapat dijadikan obyek kontrak berjangka adalah kopi, minyak kelapa sawit, plywood, karet, kakao, lada, gula pasir, kacang tanah, kedelai, cengkeh, udang, ikan, bahan bakar minyak, gas alam, tenaga listrik, emas, batubara, timah, pulp dan kertas, benang, semen dan pupuk. ${ }^{12}$ Namun yang masih diperdagangkan hingga saat ini hanya emas dan minyak kelapa sawit, melalui kontrak berjangka emas, indeks emas, gulir emas, CPO, dan olein; dengan volume transaksi yang sangat kecil. ${ }^{13}$ Sehingga tidak tercapai manfaat ekonomi, yaitu hedging terhadap emas dan minyak kelapa sawit serta referensi harga.

\section{Pelaksanaan Transaksi Kontrak Berjangka}

Untuk mempermudah pemahaman transaksi kontrak berjangka (multilateral), maka akan digambarkan alur transaksi dalam skema berikut:

${ }^{10}$ Karena baru terbentuk ketika di-matching (disepadankan) antara order jual dan order beli.

${ }^{11}$ Pasal15 UU No.32/1997 menyebutkan bahwa Bursa Berjangka dapat mengadakan transaksi fisik komoditi yang disebutkan dalam Keppres tentang Komoditi yang dapat Dijadikan Subyek Kontrak Berjangka.

${ }^{12}$ Lihat Keputusan Presiden No.119 Tahun 2001 tentang Komoditi yang Dapat Dijadikan Subyek Kontrak Berjangka.

${ }^{13}$ Pada akhir 2008, volume transaksi di BBJ hanya mencapai 53.788 lot. Bandingkan dengan volume OTC yang dilaporkan kepada BBJ mencapai 5.514.849 lot. 


\section{Skema Pelaksanaan Transaksi Kontrak Berjangka ${ }^{14}$}

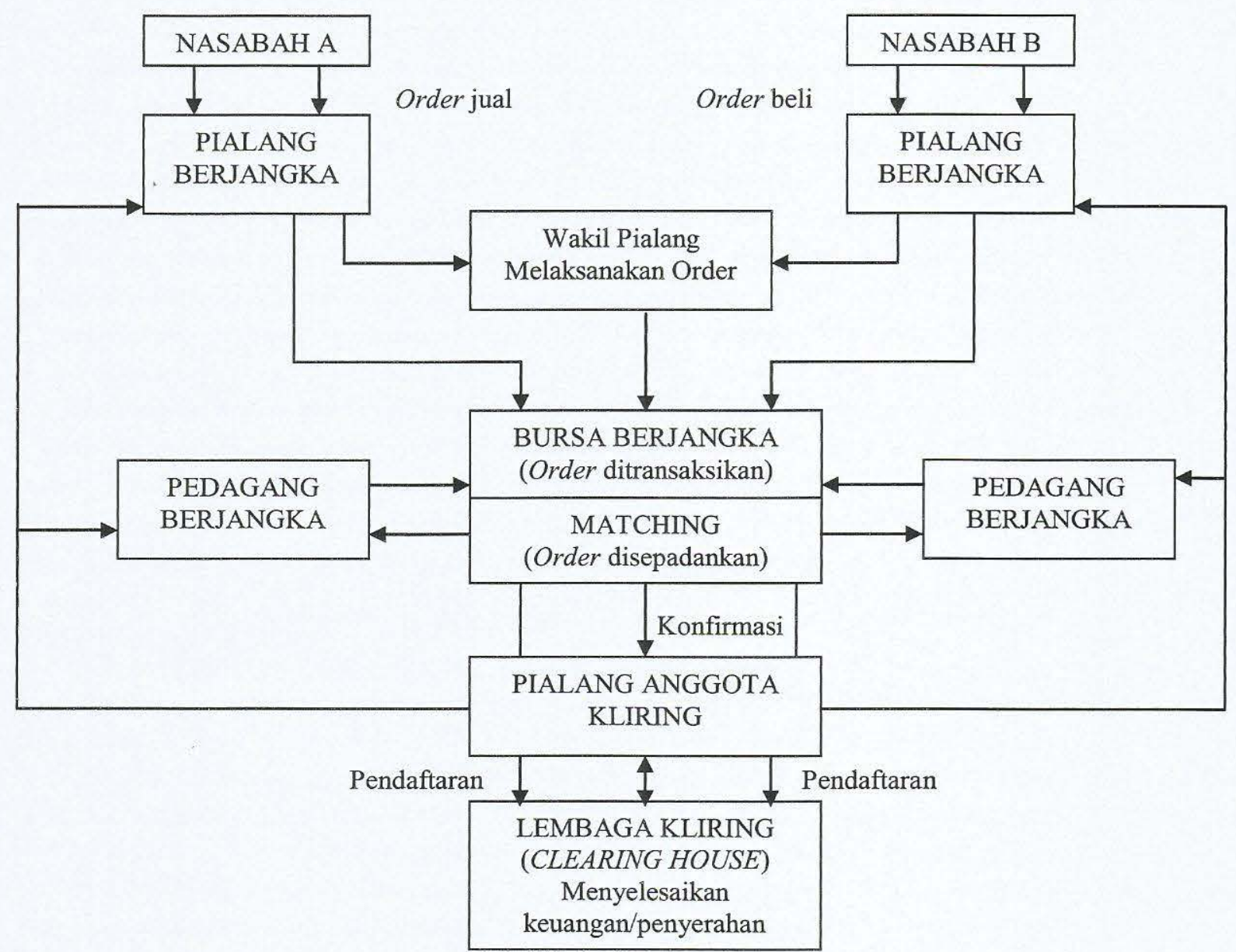

\section{Unsur-Unsur dalam Perdagangan Berjangka}

Untuk terlaksananya perdagangan berjangka, maka terdapat unsur-unsur yang mendukung terlaksananya perdagangan, yaitu:

a. Unsur pengawas

Pengawas dalam perdagangan berjangka adalah Bappebti yang kedudukannya berada di bawah Menteri Perdagangan namun dibentuk oleh undang-undang. Bappebti berwenang untuk membuat peraturan; menerbitkan izin usaha bagi bursa, lembaga kliring, serta pialang; mengawasi bursa dan lembaga kliring; melakukan pemeriksaan, penyidikan serta tindakan dan sanksi yang diperlukan untuk perlindungan masyarakat.

${ }^{14}$ Batu, "Perdagangan Berjangka", Op. Cit., hal. 137. 
b. Unsur Penyelenggara

- Bursa Berjangka

berfungsi sebagai lembaga yang menyediakan fasilitas, menyelenggarakan dan mengawasi kegiatan transaksi di pasar berjangka. Bursa berjangka merupakan self-regulatory organization $(\mathrm{SRO}){ }^{15}$ sehingga memiliki wewenang untuk membuat untuk membuat aturan dalam organisasinya. Penegakan peraturan sangat penting dalam rangka mewujudkan kepercayaan para nasabah terhadap pasar.

Di Indonesia, bursa berjangka yang telah tumbuh selama satu dekade terakhir adalah Bursa Berjangka Jakarta (BBJ). Berbeda halnya dengan negara lain, seperti Amerika Serikat yang memiliki lebih dari sepuluh bursa berjangka. Namun pada tahun 2009 ini, berdiri bursa berjangka baru di Indonesia, yaitu Indonesia Commodity and Derivatives Exchange (ICDX) yang juga berkedudukan di Jakarta.

- Lembaga Kliring Berjangka

berfungsi sebagai penjamin performance atau dipenuhinya kontrak berjangka yang diperdagangkan di bursa berjangka. Oleh sebab itu, lembaga kliring berjangka wajib memiliki kemampuan keuangan yang kuat, termasuk bagi anggotanya. Di luar negeri, dikenal dengan Clearing House. Lembaga kliring berjangka merupakan badan usaha yang menyelenggarakan dan menyediakan sistem dan/atau sarana untuk pelaksanaan kliring dan penjaminan transaksi di bursa berjangka. ${ }^{16}$ Lembaga kliring berjangka juga diberi wewenang untuk membuat peraturan dan tata tertib sendiri (SRO), termasuk sistem pelaporan, pemantauan, dan pemeriksaan terhadap anggotanya.

Lembaga kliring berjangka bertindak sebagai wakil penjual terhadap pembeli dan kebalikannya, sebagai wakil pembeli terhadap penjual. Dengan cara, sebagai akhir dari transaksi, setiap hari lembaga kliring mencocokan atau melakukan validasi maupun menyelesaikan semua transaksi pembelian dan penjualan. Dengan demikian, di dalam perdagangan berjangka pembeli dan penjual tidak perlu saling bertemu, karena posisi mereka dalam penyelesaian transaksi ini diwakili oleh lembaga kliring berjangka.

Saat ini, lembaga kliring berjangka di Indonesia yang telah berdiri adalah PT Kliring Berjangka Indonesia (PT KBI). KBI didirikan pada tahun 1984, merupakan suatu Badan Usaha Milik Negara yang seluruh sahamnya dimiliki oleh Pemerintah Republik Indonesia. ${ }^{17}$ Komoditi.

15 Berdasarkan Pasal 16 huruf (c) UU No.32/1997 tentang Perdagangan Berjangka

${ }^{16}$ Indonesia, Undang-Undang tentang Perdagangan Berjangka Komoditi, UU No.32 Tahun 1997, LN No. 93 tahun 1997, TLN No.3720, Pasal 1 angka (7). (selanjutnya disebut dengan UU Perdagangan Berjangka). 
c. Unsur Pelaku

- Pialang Berjangka (Broker)

Pialang berjangka melakukan kegiatan sebagai perantara jual-beli kontrak berjangka untuk dan atas perintah/amanat dari pihak ketiga (nasabah) dan berhak menarik uang jaminan (margin) atas setiap transaksi tersebut sesuai dengan peraturan. ${ }^{18}$ Pialang berjangka mewakili nasabahnya dalam semua urusan yang berhubungan dengan bursa berjangka dan lembaga kliring berjangka. Kegiatan usaha sebagai pialang berjangka hanya dapat dilakukan oleh anggota bursa berjangka - yang berbentuk perseroan terbatas (PT) yang telah memperoleh izin usaha pialang berjangka dari Bappebti. ${ }^{19}$

Pialang berjangka diwajibkan melaksanakan prinsip Know Your Customers (KYC). Hal ini penting dilakukan karena, salah satunya, kondisi finansial dan kredibilitas dari calon nasabah yang bersangkutan. Pialang berjangka harus menyampaikan Dokumen Keterangan Perusahaan (Company Profile) dan dokumen Pemberitahuan Adanya Risiko (Risk Disclosure Statement) kepada calon nasabah.

- Pialang Anggota Kliring

Pialang ini memiliki hak menjamin pelaksanaan transaksi. Semua transaksi di pasar berjangka hanya boleh dilaksanakan apabila telah mendapatkan jaminan dari pialang berjangka yang berstatus anggota. Oleh karena itu, persyaratan yang dikenakan kepada anggota lembaga kliring adalah harus memiliki jaminan dan kemampuan keuangan yang besar.

- Pedagang Berjangka

Pedagang berjangka adalah anggota bursa berjangka yang hanya berhak melakukan transaksi kontrak berjangka di bursa berjangka untuk rekening diri sendiri dan/atau kelompok usahanya. Para pedagang berjangka ini dipersyaratkan harus memperoleh Sertifikat Pendaftaran dari Bappebti. Hal ini dilakukan agar kegiatan para pedagang berjangka tidak mengganggu mekanisme dan dinamisasi pasar.

\section{d. Unsur Penunjang}

Perbankan adalah sebagai unsur penunjang dalam pelaksanaan perdagangan berjangka. Semua transaksi harus dijamin dengan sejumlah uang atau surat berharga, yang disebut dengan margin. Margin disimpan dan diadministrasikan oleh bank dalam rekening terpisah (segregated

${ }^{17}$ Badan Pengawas Perdagangan Berjangka Komoditi, "Layanan Kliring dan Penjaminan Penyelesaian Perdagangan Berjangka", (Jakarta: Badan Pengawas Perdagangan Berjangka Komoditi, 2008), hal. 2.

${ }^{18}$ Indonesia, UU Perdagangan Berjangka, Pasal 1 angka (13).

${ }^{19}$ Ibid., Pasal 31 ayat (1). 
account) antara dana milik nasabah dengan dana milik pialang berjangka. Dana nasabah yang terdapat dalam rekening terpisah tidak dapat ditarik oleh pialang berjangka, kecuali untuk komisi dan pengeluaran lainnya atas persetujuan nasabah.

e. Unsur Pengguna

- Hedger

pedagang atau pengusaha yang melakukan bisnis di pasar fisik atas komoditi yang kontrak berjangkanya diperdagangkan di pasar berjangka (bursa). Hedger menggunakan transaksi kontrak berjangka untuk melindungi nilai finansial dari komoditi terhadap risiko perubahan harga di pasar fisik atau pasar spot.

Hedger terbagi atas dua kelompok, ${ }^{20}$ yakni:

1). hedger pembeli/buying hedge/long hedge

Untuk melindungi nilainya, ia membeli kontrak berjangka saat ini dengan posisi long (beli/buy). Dilakukan oleh eksportir, prosesor, pemakai bahan baku, dan sebagainya. Tujuannya untuk menjaga kestabilan dan kontinuitas pasokan atau persediaan.

2). hedger penjual/selling hedge/hedge short

Untuk melindungi komoditinya, ia akan menjual kontrak berjangka sekarang dengan posisi short (jual/sell). Dilakukan oleh para produsen, terutama petani, tujuannya untuk melindungi diri dari kemungkinan penurunan harga komoditi yang akan dihasilkan atau dimilikinya, seperti hasil panen.

- Spekulator

Spekulator atau spekulan memainkan peran yang sangat penting dalam suatu bursa, karena spekulan biasanya bisa meningkatkan likuiditas pasar dengan bertindak sebagai perantara antara penjual (short hedger) yang ingin mendapatkan harga setinggi mungkin dan pembeli (long hedger) yang ingin mendapatkan harga serendah mungkin. Di sinilah spekulan memainkan peran yang sangat penting dalam mempertemukan kedua penawaran ini (bid and offer), sehingga pasar lebih memiliki likuiditas.

Melakukan spekulasi di pasar berjangka dapat mengakibatkan keuntungan maupun kerugian. Namun mereka biasanya hanya mengharapkan keuntungan. Para spekulator dalam memprediksi pergerakan harga biasanya menggunakan analisa teknikal. ${ }^{21}$

${ }^{20}$ Johanes Ariffin Wijaya, "Bursa Berjangka”, (Yogyakarta: Andi, 2006), hal. 22-23.

${ }^{21}$ Analisa teknikal merupakan analisis terhadap pola pergerakan harga di masa lampau dengan tujuan memprediksi pergerakan harga di masa yang akan datang, yang didahului dengan pengamatan harga dan data tentang perdagangan fisik maupun perdagangan berjangka. 


\section{Masuknya Kontrak Derivatif antar Mata Uang Asing dan Indeks Saham Asing dalam Industri Perdagangan Berjangka}

Amerika Serikat (AS) sebagai bagian penting perdagangan dunia, turut menjadi acuan dalam perdagangan berjangka. Pasar perdagangan berjangka komoditi pertanian bermula di Chicago pada pertengahan 1800-an. Kemudian seturut dengan perkembangan bisnis dunia, bursa Chicago mulai mengembangkan opsi atas saham dan mata uang berjangka pada awal 1970-an - sebagai alternatif karena turunnya volume transaksi komoditi berjangka.

Kedua perdagangan ini, kontrak berjangka komoditi dan kontrak berjangka finansial, merupakan produk derivatif yaitu surat berharga yang nilainya bergantung pada nilai dasar underlying assets. Underlying assets dari produk derivatif bisa berwujud (tangible) dan tidak berwujud (intangible). Mata uang, indeks, interest rate yang intangible dapat dijadikan underlying assets karena merupakan suatu komoditi berdasarkan pendapat berikut ini

\section{Money is the raw material of trade, both domestic and international. What the interest rate will be next summer, or what dollar will be worth against the German mark, concern people businesses depend on the money supply and what imported materials will cost. They use futures to hedge against sudden changes in the value of their holdings. ${ }^{22}$}

Bahwasanya uang adalah bahan baku untuk perdagangan, baik domestik maupun internasional. Apa yang akan terjadi pada tingkat suku bunga tahun mendatang, atau apakah dollar akan menguat terhadap rupiah, menjadi perhatian orang yang bisnisnya terkait dengan supply uang dan nilai dari mata uang asing. Tujuan digunakannya kontrak berjangka tersebut adalah untuk melindung-nilai jika terjadi perubahan pada nilai investasinya. Kontrak berjangka produk tertentu dengan mata uang asing yang dilaksanakan dalam mekanisme bursa adalah dapat meng-hedge nilai investasinya. ${ }^{23}$

Di Amerika Serikat, selain kontrak berjangka yang ditransaksikan di bursa, juga tetap terdapat transaksi kontrak derivatif produk keuangan di luar bursa. ${ }^{24} \mathrm{Di}$ Indonesia, yang berkembang secara pesat ${ }^{25}$ adalah kontrak derivatif produk

\footnotetext{
${ }^{22}$ Kenneth M. Morris \& Alan M. Siegel, "The Wallstreet Journal Guide to Understanding Money \& Investing”, (USA: Lightbulb Press, 1995), hal. 127.

${ }^{23}$ Misalnya, importir Amerika melakukan permintaan lebih terhadap produk buatan Inggris, maka permintaan (demand) terhadap poundsterling juga meningkat sebagai alat untuk membayarnya. (Lihat Mark J. Powers, "Starting Out in Futures Trading Sixth Edition", (USA : McGraw-Hill, 2001), hal. 208.

${ }^{24} \mathrm{Di}$ AS, OTC forex dan indeks tidak diawasi hanya diwajibkan melaporkan transaksinya kepada Commodity Futures Trading Commission (CFTC) sebagai regulator perdagangan berjangka di sana.
} 
keuangan yang dilaksanakan di luar bursa (OTC) atau bilateral. yakni antara pelaku dan pedagang terkait. Tidak ada peranan bursa di dalamnya yang berfungsi sebagai penyelenggara transaksi kontrak. Perdagangan ini adalah merupakan transaksi jual beli mata uang asing dalam bentuk sistem kontrak dengan memanfaatkan fluktuasi harga naik dan harga turun untuk memperoleh keuntungan. Memanfaatkan fluktuasi inilah yang bersifat spekulasi semata.

Mata uang asing yang diperdagangkan dalam transaksi derivatif adalah US Dollar (Amerika Serikat) dengan kode USD, Japanese Yen (Jepang) dengan kode JPY, Great Britain Poundsterling (Inggris Raya) dengan kode GBP, EURO (Uni Eropa) dengan kode EUR, Swiss Franc (Swiss), dengan kode CHF, Australian Dollar (Australia) dengan kode AUD, dan Canada Dollar (Kanada) dengan kode CAD. Waktu perdagangan mengikuti pasar Asia, Eropa, dan Amerika, sehingga dalam sehari perdagangan bisa dilakukan dalam waktu 24 jam.

Mata uang ini berasal dari negara-negara yang sangat maju atau disebut juga dengan mata uang kuat (hard currency) yaitu mata uang yang nilainya relatif stabil dan terkadang mengalami apresiasi atau kenaikan nilai dibandingkan dengan mata uang lainnya secara fluktuatif sehingga memungkinkan terjadinya perdagangan. $^{26}$

Contoh penghitungan transaksi:

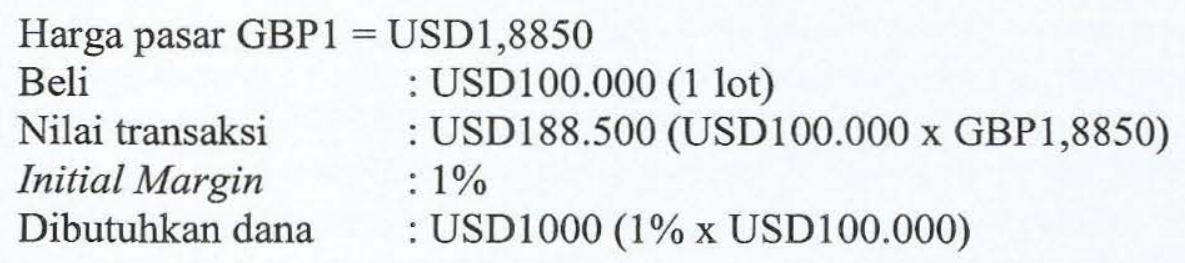

Ketika harga pasar GBP1 = USD1,8950

Jual : USD100.000 (1 lot)

Diperoleh hasil : : USD189.500 (USD100,000 x GBP1.8950)

Keuntungan : USD1000 (USD189.500-USD188.500)

Rate of return : : 100\%(USD1000/USD1000 × 100\%)

Di sini kita melihat investor melakukan open position dengan membeli 1 lot GBP (USD100.000) di mana harga GBP adalah USD1.8850. Dengan demikian, dana yang dibutuhkan adalah USD188.500, atau investor harus menyetor dana sebesar itu sebagai modal transaksi 1 lot GBP. Oleh karena itu, perdagangan dilakukan dengan sistem margin dan margin yang ditetapkan adalah $1 \%$ dari nilai kontrak, maka investor cukup menyetor modal USD1000 (1\% x USD100.000). Kekurangan sebesar USD99.000 tidak diperlukan karena dalam futures trading tidak ada penyerahan. Jadi, untuk membeli GBP senilai USD100.000 itu, investor cukup menyediakan dana USD1000.

${ }^{25}$ Pada 2007 dan 2008, volume transaksi masing-masing tahun mencapai lebih dari empat juta lot.

${ }^{26}$ Widoatmodjo, et.al., Op. Cit., hal. 17. 
Sementara itu, kontrak berjangka atas indeks saham asing mulai diperdagangkan pada 24 Februari 1982 di Kansas City Board of Trade. Indeks tersebut didasarkan dari nilai rata-rata 1700 saham. Kemudian diikuti dengan kontrak berjangka dari Standars \& Poor's (S\&P) 500 Stock Index di Chicago Mercantile Exchange serta Composite Index dan Major Market Index di New York Stock Exchange. ${ }^{27}$ Di Indonesia, kontrak derivatif indeks saham asing yang diperdagangkan adalah indeks Jepang (Nikkei 225), indeks Hongkong (Hang Seng 33), dan indeks Korea (Kospi).

Kontrak derivatif atas indeks saham asing berupa perjanjian untuk bertransaksi jual maupun beli suatu indeks saham tertentu dengan harga tertentu saat kontrak memasuki masa jatuh tempo. Nilai indeks ditentukan berdasarkan pergerakan rata-rata tertimbang (weighted average price movement) pada sebuah portofolio saham. Indeks ini selalu dihitung dengan mengalikan jumlah saham yang beredar setiap saham yang ada dalam indeks dengan harga pasarnya dan selanjutnya total nilai pasar dari semua saham tersebut dibagi dengan total jumlah saham-saham tersebut. Dalam kontrak derivatif atas indeks saham, tidak ada penyerahan aset atau sekuritas seperti halnya bertransaksi dengan saham.

At delivery time, the buyer and the seller exchange cash equal to the difference between the actual price of the product on that day and the price at which they had originally made their contract, adjusted for any daily settlements made in the meantime... ${ }^{28}$

Jadi penyelesaian transaksi dilakukan dengan menggunakan uang tunai (cash settlement). Serah terima uang tunai akan dilakukan berdasarkan perbedaan harga kontrak sesuai dengan perjanjian di awal kontrak. Contoh penghitungan transaksi:

Seorang investor memprediksi angka indeks Nikkei 225 akan menguat, maka pada tanggal 1 Agustus dia membeli NIK pada angka 9500 sebanyak 10 lot. Angka penyelesaian pada tanggal 1 Agustus adalah 9520. Pada keesokan harinya investor tersebut melikuidasi posisinya ketika angka indeks berada pada level 9530. Satuan Kontrak/Contract Multiplier $(1 \mathrm{lot})=\mathrm{Rp} 10.000$ per angka indeks.

Perhitungan laba/rugi adalah sebagai berikut:

- Pada akhir hari tanggal 1 Agustus,

Keuntungan dari kenaikan angka:

$(9520-9500) \times 10$ poin $\times \operatorname{Rp} 10.000=\operatorname{Rp} 2.000 .000,-$

- Pada akhir hari tanggal 2 Juli,

Keuntungan dari kenaikan harga:

$(9530-9530) \times 10$ poin $\times \mathrm{Rp} 10.000=\mathrm{Rp} 1.000 .000$

${ }^{27}$ Todd Lofton, "Getting Started in Futures", Third Edition, (USA: John Wiley and Sons, Inc., 1997), hal. 119.

${ }^{28}$ Powers, Op. Cit., hal. 253. 
Total keuntungan:

Rp 2.000.000 + Rp 1.000.000= Rp 3.000.000,-

\section{Permasalahan Pengaturan Kontrak Derivatif antar Mata Uang Asing dan Indeks}

Pada transaksi derivatif forex dan indeks saham asing, banyak pialang gelap. yang cenderung mengumbar janji kepada nasabah. Mereka diiming-imingi bisa dengan cepat mendapatkan untung, tanpa dijelaskan lebih lanjut mengenai risiko yang harus dipahami, dikelola dan dianalisa. Banyak nasabah akhirnya menjadi pihak yang dirugikan oleh pialang gelap yang tidak mendapat izin dari otoritas Bappebti.

Pembentukan SK SPA sebagai ketentuan teknis yang dikeluarkan oleh Bappebti semestinya mendasarkan substansinya kepada UU No.32/1997 tentang Perdagangan Berjangka Komoditi. Sementara UU No.32 Tahun 1997 tidak mengatur mengenai kegiatan transaksi derivatif yang dilakukan di luar bursa. Ketidaksesuaian ketentuan teknis tersebut terhadap UU No.32/1997 sebagai ketentuan utama pelaksanaan perdagangan berjangka, terlihat dari:

a. Jenis komoditi yang dijadikan Kontrak Berjangka (derivatives) dalam SPA tidak terdapat dalam keputusan Presiden tentang obyek Kontrak Berjangka Dalam Pasal 3 UU No.32/1997, komoditi yang dapat dijadikan obyek kontrak berjangka ditetapkan oleh Keputusan Presiden. Namun hingga saat ini, belum ada Keppres yang menetapkan forex dan indeks dapat dijadikan obyek kontrak berjangka. Dijadikannya forex dan indeks sebagai obyek kontrak derivatif, sebagaimana disebutkan dalam Pasal 4 ayat (1) SK SPA bahwa

Kontrak derivatif yang dapat diperdagangkan dalam Sistem Perdagangan Alternatif adalah kontrak derivatif antar mata uang asing (foreign cross currency) dan indeks,"

kontradiktif dengan yang dimaksud dalam Pasal 1 angka (2) jo. Pasal 3 UU No.32/1997. Oleh karena di dalamnya menyatakan bahwa komoditi yang dapat dijadikan obyek kontrak berjangka adalah yang ditetapkan dengan Keputusan Presiden.

b. Posisi Pedagang Berjangka dan Bursa Berjangka dalam SPA yang tidak memenuhi amanah undang-undang

Berdasarkan UU No.32/1997, Pedagang Berjangka ${ }^{29}$ adalah Anggota Bursa Berjangka yang hanya berhak melakukan transaksi Kontrak Berjangka di Bursa Berjangka untuk diri sendiri atau kelompok usahanya

${ }^{29}$ Pedagang Berjangka terbuka bagi berbagai bentuk badan usaha dan orang perseorangan yang berkegiatan sebagai produsen, petani perseorangan, koperasi, organisasi petani, pedagang, eksportir, dan prosesor yang ingin berperan langsung atau tidak langsung dalam Perdagangan Berjangka (penjelasan Pasal 12 ayat 4 UU No.32/1997). 
(Pasal 1 angka 14). Dalam SK SPA pun Pedagang Berjangka melakukan kegiatan jual beli kontrak derivatif untuk dan atas nama sendiri. Akan tetapi, selain untuk dan atas nama sendiri, Pedagang Berjangka juga bertindak sebagai "Bandar", yang fungsinya sebagai penyepadan harga jual dan harga beli transaksi di luar bursa. ${ }^{30}$ Ini bertentangan dengan penjelasan Pasal 57 ayat (2) huruf b UU No.32/1997, di mana disebutkan bahwa semua amanat kontak berjangka dari nasabah harus disalurkan untuk ditransaksikan di bursa berjangka. Transaksi yang diselesaikan sendiri (dibandari) oleh Pialang Berjangka di luar bursa (bucketing) adalah dilarang.

Selanjutnya, dalam UU No.32/1997 disebutkan bahwa Bursa berjangka didirikan dengan tujuan untuk menyelenggarakan transaksi kontrak berjangka yang teratur, wajar, efisien, efektif, dan transparan (Pasal 10). Kontrak berjangka yang dimaksud dalam undang-undang tentu adalah kontrak berjangka yang komoditi sebagai underlying commodity telah ditetapkan dengan Keputusan Presiden, bukan dengan keputusan lain manapun. Dalam penyelenggaraan SPA, bursa berjangka "hanya" sebagai pemantau serta memastikan seluruh transaksi yang terjadi telah dilaporkan ke Bursa Berjangka dan didaftarkan ke Lembaga Kliring Berjangka. Selain itu, Bursa Berjangka wajib menyampaikan laporan bulanan, triwulan dan tahunan atas transaksi Sistem Perdagangan Alternatif kepada Bappebti (Pasal 8 SK SPA). Dengan kata lain, bursa berjangka menjalankan fungsi tersebut di atas terhadap transaksi yang tidak terjadi di bursa. Sementara dalam undang-undang, posisi Bursa Berjangka adalah sebagai penyelenggara kontrak berjangka (derivatives) itu sendiri.

c. Mekanisme kegiatan perdagangan SPA yang diselenggarakan di luar bursa (Off ExchangelOver the Counter) bukan di dalam bursa (On Exchange)

Dalam UU No. 32/1997, hal yang diatur adalah transaksi kontrak berjangka yang terjadi di bursa berjangka (on exchange). Hal ini terlihat dari bunyi Pasal 1 angka (1) dan (2), yakni bahwa Perdagangan Berjangka, adalah segala sesuatu yang berkaitan dengan jual beli komoditi dengan penyerahan kemudian berdasarkan kontrak berjangka. Sementara komoditi yang dimaksud adalah barang dagangan yang menjadi subyek kontrak berjangka yang diperdagangkan di Bursa Berjangka. Dengan demikian, mekanisme pelaksanaan perdagangan berjangka dalam UU No.32/1997 adalah mekanisme secara multilateral, yakni perdagangan yang melibatkan banyak pihak, baik pedagang berjangka dan pialang berjangka. ${ }^{31}$ Berbeda dengan ketentuan dalam SK SPA, SPA dilaksanakan secara bilateral ${ }^{32}$. Yang dimaksud dalam perdagangan bilateral adalah peserta SPA (pialang

30 "Penyepadanan" dilakukan oleh sistem trading yang disediakan oleh pedagang SPA yang bersangkutan, sehingga dapat dikatakan membandari transaksi sendiri.

${ }^{31}$ Lihat Skema Pelaksanaan Transaksi Kontrak Berjangka.

${ }^{32}$ Berdasarkan Pasal 1 huruf (a) SK SPA. 
berjangka) meneruskan order nasabah sesuai perintah nasabah (harga dan jumlah/volume lot) ke penyelenggara SPA (pedagang berjangka). Pedagang berjangka akan mempertemukan (matching) order jual dan beli nasabah dan hasilnya yang menang atau yang rugi akan diteruskan ke peserta SPA. Dengan demikian tidak ada peran bursa berjangka yang turut menyelenggarakan transaksi ini.

d. Kegiatan perdagangan melalui SPA tidak memberikan manfaat ekonomi.

Pada UU No.32/1997 disebutkan bahwa Perdagangan Berjangka Komoditi adalah prasarana perdagangan yang dapat dimanfaatkan dunia usaha, termasuk petani, usaha kecil, dan produsen kecil, untuk melindungi dirinya dari risiko fluktuasi harga. Petani dan produsen kecil pada umumnya tidak memiliki kemampuan secara langsung dalam menggunakan sarana perdagangan berjangka. Agar mereka dapat memanfaatkan Perdagangan Berjangka Komoditi, kepentingan mereka dapat diorganisasikan melalui koperasi, kelompok pemasaran, atau pola kemitraan pengusaha dengan petani dan produsen kecil. Berangkat dari hal ini, perdagangan berjangka memiliki fungsi sebagai alat lindung nilai dan sarana pembentukan nilai (manfaat ekonomi). Perdagangan berjangka bisa juga dijadikan sebagai alternatif investasi. Manfaat inilah yang akhirnya banyak diambil oleh para pelaku perdagangan berjangka.

Dalam penyelenggaran SPA, tentu SPA tidak serta merta melindung nilai komoditi primer dan tidak dapat menghasilkan pembentukan harga. Hal ini disebabkan bahwa transaksi dilakukan hanya untuk berspekulasi mengenai fluktuasi harga atau nilai dari forex dan indeks. Forex dan indeks sendiri tidak ada kaitannya dengan komoditi yang hendak dilindungnilainya. Oleh karena itu, manfaat ekonomi (hedging dan reference price) yang dikehendaki oleh UU No.32/1997 tidak terwujud melalui perdagangan SPA. Kegiatan transaksi ini hanya untuk memperoleh keuntungan semata bagi pihak yang berspekulasi.

e. Penarikan margin yang berbeda peruntukannya dalam kegiatan SPA

Penarikan margin inilah yang menjadi dasar bagi Bappebti untuk mengatur kegiatan SPA ke dalam industri berjangka, sebagaimana disebut dalam "menimbang", yakni bahwa perdagangan bilateral kontrak derivatif dengan penarikan margin telah berkembang luas di masyarakat. Dalam Pasal 1 angka 12 jo. angka 19, pialang berjangka menarik sejumlah uang dan/atau surat berharga tertentu sebagai margin untuk menjamin transaksi kegiatan perdagangan berjangka. Margin ditempatkan oleh nasabah pada pialang berjangka, pialang berjangka pada anggota kliring berjangka, atau anggota kliring berjangka pada lembaga kliring berjangka untuk menjamin pelaksanaan transaksi kontrak berjangka. Berarti margin yang dimaksudkan oleh undang-undang adalah margin untuk menjamin pelaksanaan transaksi yang terjadi di bursa. Sementara margin dalam SK SPA hanya terjadi di antara pedagang dan peserta SPA, berarti pelaksanaan jaminan untuk transaksi di luar bursa. Ini berbeda dengan yang diatur oleh undang-undang. 


\section{Dibentuknya Badan Arbitrase Perdagangan Berjangka Komoditi (BAKTI)}

Bappebti menetapkan bahwa perdagangan derivatif forex dan indeks adalah sebagai perdagangan alternatif, berarti bukan sebagai perdagangan utama dalam industri berjangka. Padahal justru transaksi derivatif forex dan indeks inilah yang banyak "menyokong" kondisi finansial Bursa Berjangka Jakarta dan total volume transaksinya jauh lebih besar dibandingkan transaksi kontrak berjangka multilateral. Transaksi derivatif forex dan indeks rata-rata tiap hari sebesar 25.000 lot sedangkan transaksi kontrak berjangka kurang dari 50 lot. Atas dasar pertimbangan tersebut serta beban moral untuk melindungi masyarakat, kemudian Bappebti mengeluarkan SK yang bersangkutan. Namun justru pengaturan dalam SK tidak masuk dalam yurisdiksi UU Perdagangan Berjangka. Oleh sebab itu, hal ini berdampak pula bagi penyelesaian kasus yang terjadi dalam perdagangan kontrak derivatif yang dialami nasabah. Kasus yang diadukan nasabah pada saat dilakukan di pengadilan mengalami kesulitan karena pengaturannya tidak ada dalam ketentuan yang ada dalam UU No.32/1997, sehingga sanksi tidak dapat diberikan sebagaimana diatur oleh UU dan peraturan pelaksanaannya.

Berkenaan dengan sulitnya penyelesaian kasus SPA di pengadilan, BBJ, KBI, Asosiasi Pialang Berjangka Indonesia dan Ikatan Perusahaan Pedagang Berjangka Indonesia membentuk Badan Arbitrase Perdagangan Berjangka Komoditi (BAKTI). BAKTI diresmikan pada tanggal 7 November 2008. Melalui arbitrase, nasabah yang merasa dirugikan para pihak dapat memilih arbiter yang menurut keyakinannya mempunyai pengetahuan, pengalaman serta latar belakang yang cukup mengenai masalah yang disengketakan, jujur dan adil. Selain itu, penyelesaian kasus terhitung lebih cepat dan efisien karena putusannya final and binding. Untuk itulah peranan arbitrase sangat penting dalam penyelesaian kasus SPA, yang terbentur dengan masalah pengaturannya, sehingga dapat diselesaikan untuk mencapai rasa keadilan dan kepatutan (ex aequo et bono).

\section{Penutup}

Bappebti mengeluarkan SK SPA pada dasarnya adalah untuk memberikan kepastian hukum dan dalam rangka memberikan perlindungan kepada nasabah (customer protection) dalam transaksi bilateral di luar bursa. Pada kenyataannya, kepastian hukum SPA dalam rangka melindungi nasabah yang menjadi pihak dirugikan tidak tercapai. Oleh karena hingga sekarang kasus yang terjadi akibat transaksi derivatif forex dan juga indeks saham asing tidak mampu dituntaskan dengan dasar UU No.32 Tahun 1997 tentang Perdagangan Berjangka Komoditi sebagai peraturan perundang-undangan yang memberikan kewenangan kepada Bappebti untuk mengawasi perdagangan berjangka. Hal ini disebabkan karena SK SPA bertentangan dengan UU No.32/1997. Ketidaksesuaian tersebut dapat dilihat ketika kita meninjau ulang substansi SK SPA, di mana transaksi ini ternyata tidak sejalan dengan apa yang diatur dalam UU No.32/1007. Ketidaksesuaian ini menunjukkan bahwa ketentuan SK SPA tidak memenuhi amanah undang-undang sebagai peraturan pelaksana, yaitu penjelasan lebih lanjut yang bersifat teknis atas 
UU No.32/1997 yang secara hirarki berada diatasnya. Akibatnya transaksi derivatif di luar bursa tersebut tidak memiliki payung hukum yang kuat dalam hal penyelenggaraannya dalam skema perdagangan berjangka.

Untuk mewujudkan kepastian hukum yang efektif bagi perdagangan derivatif forex dan indeks, pemerintah harus secepatnya melakukan perubahan atas UU No.32/1997 serta mencabut SK SPA tersebut. Perubahan perlu dilakukan agar dapat mengatur secara lebih komprehensif mengenai perdagangan berjangka, baik di dalam bursa maupun di luar bursa. Undang-undang harus turut mengikuti perkembangan yang terjadi dalam masyarakat sehingga undang-undang mampu mengakomodasi kepentingan masyarakat secara umum. Perangkat hukum yang kuat sangat diperlukan untuk mengontrol transaksi derivatif ini. Kelima hal yang bisa dilaksanakan bursa berjangka bersama dengan Bappebti terkait SPA ialah penyusunan prosedur operasional standar pelayanan nasabah, perbaikan sistem perdagangan, sosialisasi serta edukasi secara berkelanjutan (seperti training secara komprehensif bagi para calon investor), mengoptimalkan lembaga arbitrase (Badan Arbitrase Perdagangan Berjangka Komoditi - BAKTI) serta penegakan peraturan. Selain itu, dengan mengendalikan SPA ini melalui peran bursa berjangka, maka fee yang didapat dari pelaksanaan transaksi bisa dimanfaatkan untuk mengembangkan kontrak berjangka multilateral. Dengan demikian, bursa berjangka dapat kembali kepada kittah-nya untuk menyelenggarakan kontrak berjangka multilateral secara optimal. 


\section{Daftar Pustaka}

\section{Buku}

Badan Pengawas Perdagangan Berjangka Komoditi. Layanan Kliring dan Penjaminan Penyelesaian Perdagangan Berjangka, Jakarta: Badan Pengawas Perdagangan Berjangka Komoditi, 2008.

- Sekilas tentang Perdagangan Berjangka Komoditi, Jakarta: Badan Pengawas Perdagangan Berjangka Komoditi, 2006.

. Tuntunan Praktis: Investasi, Hedging, \& Mekanisme Transaksi. Jakarta: Bappebti.

. Tuntunan Praktis Perdagangan Berjangka: Pengantar \& Peraturan. Jakarta: Bappebti.

Batu, Pantas Lumban. Perdagangan Berjangka (Futures Trading), Jakarta: Dian Utama, 2008.

Fink, Robert E. \& Robert B. Feduniak. Futures Trading: Concepts and Strategies, New York: New York Institute of Finance, 1988.

Lofton, Todd. Getting Started in Futures, Third Edition, USA: John Wiley and Sons, Inc., 1997.

Morris, Kenneth M. \& Alan M. Siegel. The Wallstreet Journal Guide to Understanding Money \& Investing, USA: Lightbulb Press, 1995.

National Futures Association. Trading in the Retail Off-Exchange Foreign Currency Market: What Investors Need To Know, Chicago: National Futures Association.

Powers, Mark J. Starting Out in Futures Trading, Sixth Edition. USA: McGraw-Hill, 2001.

Widoatmodjo, Sawidji, et.al. Forex Online Trading, Jakarta: Gramedia, 2008.

Wijaya, Johanes Ariffin. Bursa Berjangka, Yogyakarta: Andi, 2006.

\section{Peraturan}

Indonesia. Undang-Undang tentang Perdagangan Berjangka Komoditi, UU No.32 Tahun 1997. LN No. 93 Tahun 1997. TLN No.3720.

. Keputusan Presiden tentang Komoditi yang Dapat Dijadikan Subjek Kontrak Berjangka, Keppres RI No.119 Tahun 2001.

Badan Pengawas Perdagangan Berjangka Komoditi. Keputusan Kepala Bappebti tentang Sistem Perdagangan Alternatif, Keputusan No.55/Kep/BAPPEBTI/I/2005. 


\section{Artikel}

"About CFTC: An Important Mission in the Ever-Changing World of Finance", <http://www.cftc.gov/aboutthecftc/index.htm>, diakses tanggal 26 Mei 2009.

Mahmud, Hasan Zein. "Beberapa Pokok Pikiran tentang Perbaikan SPA", <http://www.bbj-jfx.com/node/663>, Diakses tanggal 8 April 2009.

Zumar, Dhorifi. "BBJ Melenceng dari Kittah" dalam Prospek Perdagangan Berjangka di Indonesia, Bisnis Indonesia, 9 Juli 2003. 